\title{
105. Der Dickdarmschleimhautpolyp als Begleitbefund beim Colon- und Rectumcarcinom
}

\author{
R. Roka, U. Wayand und D. Depisch \\ 1. Chirurgische Universitätsklinik, Wien
}

\section{Concomitant Polyps of the Large Intestine in Colorectal Carcinomas}

Summary. The pathological specimens taken from 123 patients with colorectal carcinoma (Group A) included 143 polyps. These were compared histologically with 117 polyps taken from patients who did not have carcinoma of the large bowel (Group B). The incidence of carcinoma in situ was significantly higher in Group A (14\% as against $6.8 \%$ in Group B). The difference in the incidence of invasive carcinoma between the two groups was not significant. The malignant polyps found in Group $B$ were on average two-and-a-half times the size of those in Group A. Of the polyps taken from patients in Group A, 74 percent were located within $6 \mathrm{~cm}$ of the carcinoma.

Key words: Carcinoma, colorectal, intestinal - Polyp, colorectal, intestinal.

Zusammenfassung. 143 Polypen aus den Resektionspräparaten von 123 Patienten mit Colon- oder Rectumcarcinom (Gruppe A) wurden untersucht. Es erfolgte ein histologischer Vergleich mit 117 Polypen malignomfreier Patienten (Gruppe B). Das Carcinoma in situ war in Gruppe A signifikant häufiger (14\% in A, 6,8\% in B). Nicht signifikant war die Differenz an Polypen mit invasivem Carcinom. Polypen mit malignem Befund der Gruppe B waren durchschnittlich $2 \frac{1}{2}$ mal so groß wie die der Gruppe A. 74\% aller Polypen der Gruppe A lagen innerhalb einer $6 \mathrm{~cm}$ breiten Zone beidseits des Carcinoms.

Schliisselwörter: Dickdarmschleimhautpolyp und Carcinom - Dickdarmcarcinome und Polypen.

\section{Klinik, Therapie und Prognose des intestinalen Carcinoid}

\author{
G. Peres und M. Umran
}

Krankenhaus Detmold, Chirurgische Klinik I, D-4930 Detmold

\section{Clinical Features, Treatment and Prognosis of Intestinal Carcinoid}

\begin{abstract}
Summary. In 25 patients with intestinal carcinoid, the carcinoid was located variously in the duodenum, appendix and colon. The youngest patient was 10 and the oldest 77 years of age. In 5 of 11 patients with carcinoid of the appendix, symptoms of acute appendicitis were found. In 3 cases the patients presented signs of cronic appendicitis and 3 patients hat pelveopathy. In 4 cases carcinoid of the rectum was a chance finding during examination for hemorrhoids. Various operations were performed in these patients: exstirpation of the tumor, duodenojejunostomy resection, appendectomy, hemicolectomy, in 4 cases lokal exstirpation. Prognosis: 8 months to 9 years.
\end{abstract}

Key words: Carcinoid, intestinal - Treatment - Features, clinical - Prognosis. 